\title{
PENGARUH PENERAPAN STRATEGI PEMBELAJARAN "THINK, TALK, WRITE” TERHADAP KEMAMPUAN PEMAHAMAN KONSEP DAN KOMUNIKASI MATEMATIKA SISWA KELAS III N KECAMATAN LEMBAH GUMANTI
}

\author{
THE EFFECT OF APPLICATION OF "THINK, TALK, WRITE" \\ LEARNING STRATEGY TOWARD STUDETS' MATH CONCEPT AND \\ COMMUNICATION SKILLOF GRADE VIII, SMP N KECAMATAN \\ LEMBAH GUMANTI
}

\author{
Asmaul Husna \\ Pendidikan Matematika, Universitas Riau Kepulauan, Batam, Indonesia \\ asmaul@fkip.unrika.ac.id
}

\begin{abstract}
Abstrak
Kemampuan memahami konsep-konsep matematika dan keterampilan komunikasi adalah tujuan pembelajaran matematika sebagaimana yang dinyatakan oleh Departemen Pendidikan, dan merupakan aspek yang sangat penting dalam belajar matematika. Kurangnya keterampilan komunikasi dan pemahaman konsep-konsep matematika siswa akan mempengaruhi kualitas belajar siswa yang menghasilkan prestasi siswa rendah di sekolah, itu juga terjadi di SMP N Lembah Gumanti. Think Talk Write learning strategies adalah salah satu alternatif untuk meningkatkan keaktifan dan kreativitas siswa dalam belajar. Penelitian ini adalah Quasi Experiment. Populasi dalam penelitian ini adalah siswa dari SMP N Lembah Gumanti Kabupaten. Sampel dalam penelitian ini adalah siswa kelas VIII 1 SMP N 3 Lembah Gumanti sebagai kelas eksperimen dan siswa kelas VIII 2 kelas sebagai kelas kontrol yang dipilih secara acak. Instrumen yang digunakan adalah tes tertulis. Data yang diperoleh dianalisis menggunakan uji ANCOVA (analisis Kovarian. Hasil penelitian menunjukkan bahwa kemampuan pemahaman konsep secara keseluruhan dan kemampuan siswa yang diajarkan dengan menggunakan low initial learning strategy awal TTW lebih tinggi daripada siswa diajarkan dengan pembelajaran konvensional, keterampilan komunikasi dan strategi yang mampu keseluruhan tinggi awal pembelajaran yang diajarkan oleh TTW lebih tinggi dari siswa yang diajar oleh pembelajaran konvensional
\end{abstract}

Kata Kunci: Strategi Pembelajaran Kooperatif TipeThink Talk Write, Kemampuan Awal, Kemampuan Pemahaman Konsep Dan Kemampuan Komunikasi Matematis.

\begin{abstract}
The ability of understanding mathematical concepts and communication skills was a math learning goals stated by the Ministry of Education, and was a very important aspect in learning mathematics. Lack of
\end{abstract}


communication skills and understanding of mathematical concepts students will affect the quality of student learning that result in low student achievement in school, it was also happening in SMP N Lembah Gumanti. Think Talk Write learning strategies was one alternative to improve the liveliness and creativity of students in learning.This research is a Quasi Experiment. The population in this study were students of SMP N Lembah Gumanti District. The samples in this study were students of class VIII 1 SMP $N 3$ Lembah Gumanti as experimental class and VIII 2 grade students as a class randomly selected controls. Instrument used was a written test. The data obtained were analyzed using ANCOVA test (analysis of Covariance).The results showed that the ability of understanding the overall concept and capable students who are taught by low initial learning strategy TTW higher than students taught with conventional learning, communication skills and capable overall high initial learning strategies taught by TTW higher than the students who taught by conventional learning.

Keywords: of"think, talk, write"learning strategy, plimary ability, kemampuan awal, math concept and communicationskill.

\section{PENDAHULUAN}

Matematika dapat dikatakan sebagai landasan bagi perkembangan ilmu pengetahuan dan teknologi, karena matematika dapat mengembangkan kemampuan berfikir logis, analitis, kritis, kreatif dan sistematis serta kemampuan bekerja sama (Cockroft dalam Mulyono 2009:251).

Seiring dengan perkembangan ilmu pengetahuan, pemerintah melakukan berbagai usaha untuk meningkatkan mutu pendidikan begitupun dengan matematika. Usaha yang dilakukan pemerintah diantaranya melengkapi sarana dan prasarana, mengembangkan dan memperbaharui kurikulum. Berbagai usaha yang telah dilakukan tersebut belum memperlihatkan hasil yang memuaskan.

Berdasarkan observasi yang dilakukan di salah satu SMP Kecamatan Lembah Gumanti, tepatnya di SMP N 3 Lembah Gumanti. Didapatkan informasi tentang pembelajaran matematika, diantaranya strategi pembelajaran yang diterapkan kurang bervariasi dan proses pembelajaran yang cenderung terpusat pada guru. Siswa tidak dibiasakan berdiskusi sehingga siswa kurang memahami konsep dengan baik, akibatnya pola belajar siswa lebih bersifat menghafal, ini mengakibatkan materi pelajaran yang diterima kurang tersimpan dan cepat hilang dari ingatan siswa bahkan siswa cenderung melupakannya.

Dari semua kondisi yang ditemukan dan telah dijelaskan sebelumnya, salah satu usaha yang dapat dilakukan dalam proses pembelajaran khususnya peningkatan kemampuan pemahaman konsep dan komunikasi matematis siswa adalah penggunaan pembelajaran 
yangmemotivasi siswa untuk memahami akan kegunaan materi yang dipelajari, menfasilitasi kebutuhan siswa untuk berdiskusi dan bekerja sama. Selain itu, juga dapat membantu siswa dalam mengembangkan kemampuan pemahaman konsep dan kemampuan komunikasi matematis siswa.

Strategi yang dirasa cocok untuk diterapkan pada kondisi ini adalah pembelajaran kooperatif yang dalam teorinya merupakan salah satu solusi untuk membantu siswa belajar dengan lebih baik lagi. Melalui pembelajaran kooperatif siswa dapat berkomunikasi dengan temannya dan saling membantu untuk memecahkan masalah bersama.

Pembelajaran kooperatif terdiri dari berbagai macam strategi, namun pembelajaran yang digunakan dalam penelitian ini adalah strategi pembelajaran Think Talk Write (TTW).Pada awal pembelajaran, guru mencoba memberikan ulasan singkat mengenai materi yang akan dipelajari, Kemudian guru memberikan LKS kepada masing-masing siswa secara berkelompok. Setelah itu siswa akan melaksanakan langkah-langkah dalam strategi TTW, pertama yaitu tahap Think (berpikir), siswamembaca teks berupa soal dari LKS. Dalam tahap ini siswa secara individu memikirkan kemungkinan jawaban (strategi penyelesaian), pada tahap ini diperkirakan akan mampu melatih kemampuan pemahaman siswa terhadap konsep yang telah dipelajari.

Tahap kedua adalah talk (berbicara atau diskusi) memberikan kesempatan kepada siswa untuk membicarakan tentang penyelidikannya pada tahap pertama. Kemampuan komunikasi siswa akan terlihat pada dialognya dalam berdiskusi baik dalam bertukar ide dengan orang lain ataupun refleksi mereka sendiri yang diungkapkannya kepada orang lain.

Tahap ketiga adalah write, siswa menuliskan ide-ide yang diperolehnya dari kegiatan tahap pertama dan kedua. Pada tahap ini diperkirakan akan lebih melatih kemampuan pemahaman konsep dan komunikasi matematika siswa, karena pada tahap ini tidak hanya sekedar pemahaman konsep yang dituntut tetapi juga kemampuan siswa mengkomunikasikan apa yang mereka pahami kedalam kalimat matematika.

Dapat disimpulkan bahwa strategi pembelajaran TTW (Think Talk Write) adalah suatu strategi pembelajaran dengan alur yang dimulai dari keterlibatan siswa dalam berfikir (think) atau berdialog dengan dirinya sendiri setelah proses membaca, selanjutnya berbicara (talk) dan 
membagi ide (sharing) dengan temannya sebelum menulis (write). Lebih rinci dalam penelitian ini langkah-langkah pembelajaran dengan strategi TTW yang digunakan adalah:

1. Guru memberi ulasan singkat tentang materi yang akan dipelajari.

2. Guru membagikan LKS kepada masing-masing siswa secara berkelompok.

3. Siswa memahami materi yang ada dalam LKS

4. Siswa membaca masalah yang ada dalam LKS dan membuat catatan kecil secara individu tentang apa yang ia ketahui dan tidak ketahui dalam masalah tersebut. Ketika siswa membuat catatan kecil inilah akan terjadi proses berpikir (think) pada siswa. Setelah itu siswa berusaha untuk meyelesaikan masalah tersebut secara individu. Kegiatan ini bertujuan agar siswa dapat membedakan atau menyatukan ide-ide yang terdapat pada bacaan untuk kemudian diterjemahkan ke dalam bahasa sendiri.

5. Siswa berdiskusi dengan teman dalam kelompok membahas isi catatan yang dibuatnya dan penyelesaian masalah dikerjakan secara individu (talk). Dalam kegiatan ini mereka menggunakan bahasa dan kata-kata mereka sendiri untuk menyampaikan ide-ide matematika dalam diskusi. Diskusi diharapkan dapat menghasilkan solusi atas soal yang diberikan. Diskusi akan efektif jika anggota kelompok tidak terlalu banyak dan terdiri dari anggota kelompok dengan kemampuan yang heterogen. Hal ini sejalan dengan pendapat Huinker dan Laughlin (Maula, 2012:5) yang menyatakan bahwa metode TTW akan efektif ketika siswa bekerja dalam kelompok yang heterogen yang terdiri dari 2 sampai 6 siswa yang bekerja untuk menjelaskan, meringkas, atau merefleksi.

6. Dari hasil diskusi, siswa secara individu merumuskan pengetahuan berupa jawaban atas soal (berisi landasan dan keterkaitan konsep, metode, dan solusi) dalam bentuk tulisan (write) dengan bahasanya sendiri. Pada tulisan itu siswa menghubungkan ide-ide yang diperolehnya melalui diskusi.

7. Perwakilan kelompok menyajikan hasil diskusi kelompok, sedangkan kelompok lain diminta memberikan tanggapan.

8. Kegiatan akhir pembelajaran adalah membuat refleksi dan kesimpulan atas materi yang dipelajari. Sebelum itu dipilih beberapa atau satu orang Siswa sebagai perwakilan kelompok untuk menyajikan jawabannya, sedangkan kelompok lain diminta memberikan tanggapan. 
Pemahaman konsep matematis adalah salah satu tujuan penting dalam pembelajaran, memberikan pengertian bahwa materi-materi yang diajarkan kepada siswa bukan sebagai hafalan tetapi lebih jauh lagi.

Pemahaman konsep matematis juga merupakan salah satu tujuan dari setiap materi yang disampaikan oleh guru, sebab guru merupakan pembimbing siswa untuk mencapai konsep yang diharapkan. Hal ini sesuai dengan Hudojo (1998:5) yang menyatakan : “ Tujuan mengajar adalah agar pengetahuan yang disampaikan dapat dipahami peserta didik ". Pendidikan yang baik adalah usaha yang berhasil membawa siswa kepada tujuan yang ingin dicapai yaitu agar bahan yang disampaikan dipahami sepenuhnya oleh siswa.

Dalam penelitian ini indikator-indikator yang digunakan yaitu, (1) Menyatakan ulang sebuah konsep, (2) Memberikan contoh dan non contoh dari konsep, (3) Menyajikan konsep dalam berbagai bentuk representasi matematis, (4) Mengaplikasikan konsep ke pemecahan masalah. Indikator Mengklasifikasi objek menurut sifat-sifat tertentu sesuai dengan konsepnya tidak digunakan karena telah terwakili oleh indikator memberikan contoh dan non contoh dari konsep, dan indikator mengembangkan syarat perlu atau syarat cukup dari suatu konsep juga tidak digunakan karena telah terwakili oleh indikator mengaplikasikan konsep ke pemecahan masalah.

Komunikasi adalah sebuah cara berbagi ide-ide dan memperjelas pemahaman konsep, maka melalui komunikasi ide-ide direfleksikan, diperbaiki, didiskusikan, dan diubah. Sudrajat (2001:11) mengatakan ketika seorang siswa memperoleh informasi berupa konsep matematika yang diberikan guru maupun yang diperoleh dari bacaan, maka saat itu terjadi transformasi informasi matematika dari sumber kepada siswa tersebut. Siswa akan memberikan respon berdasarkan interpretasinya terhadap informasi itu. Masalah yang sering timbul adalah respon yang diberikan siswa atas informasi yang diterimanya tidak sesuai dengan apa yang diharapkan. Hal ini mungkin terjadi karena karakteristik dari matematika yang sarat dengan istilah dan simbol, sehingga tidak jarang ada siswa yang mampu menyelesaikan soal matematika dengan baik, tetapi tidak mengerti apa yang sedang dikerjakannya.

Indikator kemampuan komunikasi yang digunakan dalam penelitian ini adalah (1) menyatakan atau menggambarkan situasi masalah secara tertulis ataupun gambar, (2) melakukan 
manipulasi matematika, (3) menarik kesimpulan dari pernyataan. Sedangkan indikator mengajukan dugaan, indikator Menemukan pola atau sifat dari gejala matematis untuk membuat generalisasi tidak digunakan karena sudah terwakili oleh indikator melakukan manipulasi matematika, indikator Menarik kesimpulan, menyusun bukti, memberikan alasan atau bukti terhadap beberapa pupolasi dan indikator memeriksa kesahihan suatu argumen terwakili oleh indikator menarik kesimpulan dari pernyataan.

\section{METODOLOGI}

Penelitian ini menggunakan pendekatan kuantitatif dalam bentuk Quasi Experimental Design, dimana variabel penelitian tidak memungkinkan untuk dikontrol secara penuh. Penelitian ini menggunakan dua kelompok sampel yaitu kelompok eksperimen dan kelompok kontrol. Kelompok eksperimen adalah kelompok siswa yang memperoleh pembelajaran dengan strategi TTW Sedangkan kelompok kontrol merupakan kelompok siswa yang mengikuti pembelajaran dengan pembelajaran konvensional yaitu cara biasa yang digunakan di kelas tersebut, kepada dua kelompok diberikan tes akhir.Pada penelitian ini yang menjadi variabel bebas adalah strategi pembelajaran Think-Talk-Write dan pembelajaran konvensional.Pada penelitian ini yang merupakan variabel terikat adalah kemampuan pemahaman konsep dan kemampuan komunikasi matematis siswa setelah diberi perlakuan berupa strategi pembelajaran TTW dikelas eksperimen dan pembelajaran konvensional dikelas kontrol.Pada penelitian ini yang menjadi variabel moderator adalah kemampuan awal siswa.

Populasi pada penelitian ini adalah siswa kelas VIII SMP Kecamatan Lembah Gumanti. Karena keterbatasan penulis diambil tiga sekolah yang jaraknya tidak terlalu berjauhan, yaitu SMP N 1, SMP N 2 dan SMP N 3 Lembah Gumanti sebagai populasi. Sesuai dengan masalah yang diteliti dan metode penelitian yang digunakan, maka dibutuhkan dua kelas sebagai sampel, yaitu kelas eksperimen dan kelas kontrol. Penulis menggunakan teknikRandomSampling untuk memperoleh sampel sehingga didapat kelas VIII 1 SMP N 3 Lembah Gumanti sebagai kelas eksperimen dan kelas VIII 2 sebagai kelas kontrol.

Inatrumen yang digunakan adalah tes kemampuan pemahaman konsep dan kemampuan komunikasi matematis dan angket untuk siswa kelas eksperimen. Analisis data menggunakan uji Ancova untuk semua hipotesis. Pengujian hipotesis dibantu dengan SPSS. 


\section{HASIL PENELITIAN DAN PEMBAHASAN}

Analisis data dilakukan untuk mengungkapkan kemampuan pemahaman konsep dan kemampuan komunikasi matematis siswa setelah dilaksanakan strategi pembelajaran TTW. kemampuan pemahaman konsep dan kemampuan komunikasi matematis siswa berkemampuan awal tinggi dan siswa berkemampuan awal rendah.

Berdasarkan perhitungan diketahui bahwa rata-rata kemampuan pemahaman konsep matematis siswa yang diajar dengan strategi TTW pada indikator menyatakan ulang sebuah konsep, memberikan contoh dan non contoh dari konsep, menyajikan konsep dalam berbagai bentuk representasi matematis dan mengaplikasikan konsep ke pemecahan masalah lebih tinggi dari rata-rata kemampuan pemahaman konsep siswa yang diajar dengan pembelajaran konvensional.

Kemampuan pemahaman konsep siswa berkemampuan awal tinggi memberikan gambaran bahwa rata-rata kemampuan pemahaman konsep matematis siswa berkemampuan awal tinggikelas eksperimen tidak lebih tinggi dari rata-rata kemampuan pemahaman konsep siswa berkemampuan awal tinggipada kelas kontrol.

Kemampuan pemahaman konsep siswa berkemampuan awal rendah memberikan gambaran bahwa rata-rata kemampuan pemahaman konsep matematis siswa berkemampuan awal rendahkelas eksperimen lebih tinggi dari rata-rata kemampuan pemahaman konsep siswa berkemampuan awal rendahpada kelas kontrol.

Berdasarkan perhitungan diketahui bahwa rata-rata kemampuan komunikasi matematis siswa yang diajar dengan strategi TTW pada indikator kemampuan siswa menyatakan atau menggambarkan situasi masalah ke dalam gambar ataupun diagram, melakukan manipulasi matematika dan membuat kesimpulan dari pernyataan lebih tinggi dari rata-rata kemampuan komunikasi matematis siswa yang diajar dengan pembelajaran konvensional.

Kemampuan komunikasi matematis siswa berkemampuan awal tinggi memberikan gambaran bahwa rata-rata kemampuan komunikasi matematis siswa berkemampuan awal tinggi pada kelas eksperimen lebih tinggi dari rata-rata kemampuan komunikasi siswa berkemampuan awal tinggi pada kelas kontrol. 
Kemampuan komunikasi matematis siswa berkemampuan awal rendah memberikan gambaran bahwa rata-rata kemampuan komunikasi matematis siswa yang berkemampuan awal rendah pada kelas eksperimen lebih tinggi dari rata-rata kemampuan komunikasi siswa yang berkemampuan awal rendah pada kelas kontrol.

Uji hipotesis pertama diperoleh nilai signifikansi $=0,000$ berarti $H_{0}$ ditolak atau kemampuan pemahaman konsep siswa yang diajar dengan strategi pembelajaran TTW lebih tinggi daripada kemampuan pemahaman konsep siswa yang diajar dengan pembelajaran secara konvensional.

Uji hipotesis kedua diperoleh nilai signifikansi $=0,224$ berarti $H_{0}$ ditolak atau kemampuan pemahaman konsep siswa berkemampuan awal tinggi yang diajar dengan strategi pembelajaran TTW sama dengan kemampuan pemahaman konsep siswa berkemampuan awal tinggi yang diajar dengan pembelajaran secara konvensional.

Uji hipotesis ketiga diperoleh nilai signifikansi $=0,001$ berarti $H_{0}$ ditolak atau kemampuan pemahaman konsep siswa berkemampuan awal rendah yang diajar dengan strategi pembelajaran TTW lebih tinggi daripada kemampuan pemahaman konsep siswa berkemampuan awal rendah yang diajar dengan pembelajaran secara konvensional.

Uji hipotesis keempat diperoleh nilai signifikansi=0,000berarti $H_{0}$ ditolak atau kemampuan komunikasi matematis siswa yang diajar dengan strategi pembelajaran TTW lebih tinggi daripada kemampuan komunikasi matematis siswa yang diajar dengan pembelajaran secara konvensional.

Uji hipotesis kelima diperoleh nilai signifikansi $=0,024$ berarti $H_{0}$ ditolak atau kemampuan komunikasi matematis siswa berkemampuan awal tinggi yang diajar dengan strategi pembelajaran TTW lebih tinggi daripada kemampuan komunikasi matematis siswa yang diajar dengan pembelajaran secara konvensional.

Uji hipotesis keenam diperoleh nilai signifikansi $=0,119$ berarti $H_{0}$ diterima atau kemampuan komunikasi matematis siswa berkemampuan awal rendah yang diajar dengan strategi pembelajaran TTW sama dengan kemampuan komunikasi matematis siswa berkemampuan awal rendah yang diajar dengan pembelajaran secara konvensional.

Pembentukan kelompok dalam strategi pembelajaran adalah secara heterogen sesuai dengan kemampuan akademik. Dalam setiap kelompok ada siswa yang berkemampuan tinggi, sedang dan rendah sehingga mereka dapat saling membantu satu sama lain dalam proses pembelajaran. 
Proses pembelajaran TTWini mampu menumbuhkan rasa tanggung jawab setiap anggota kelompok dengan kata lain siswa yang berkemampuan tinggi dapat menjelaskan kepada anggota kelompoknya yang belum memahami materi yang mereka diskusikan.

Berdasarkan pengujian hipotesis pertama diperoleh pemahaman konsep siswa yang belajar dengan strategi pembelajan TTW lebih tinggi dari pada siswa yang belajar dengan pembelajaran konvensional. Hasil yang diperoleh tersebut, memperlihatkan bahwa siswa yang belajar dengan strategi TTW dalam kelompok memberikan perolehan hasil yang lebih tinggi dari pada siswa yang belajar secara konvensional. Hal ini dimungkinkan karena pembelajaran telah merubah paradigma pembelajaran yang berpusat pada guru kepada pembelajaran yang menekankan pada keaktifan siswa untuk mengkonstruksi pengetahuannya sendiri.

Dari pengamatan di kelas eksperimen siswa berkemampuan awal tinggi masih kurang berinteraksi dengan teman sekelompoknya karena merasa takut nilai teman sekelompoknya sama dengan nilai siswa tersebut, guru sudah memberi arahan bahwa dengan menjelaskan serta mengulang kembali konsep-konsep yang sedang dipelajari pada saat membantu teman sekelompok akan membuat siswa berkemampuan awal tinggi akan lebih maksimal memahami konsep yang dipelajari. Sesuai dengan yang dikemukakan Yamin (2008:90) bahwa pada tahap talk siswa berinteraksi dan berkolaborasi dengan teman untuk membahas isi catatan, setelah itu baru siswa mengkonstruksi sendiri pengetahuan sebagai hasil kolaborasi. Namun masih tetap ada siswa berkemampuan awal tinggi yang tidak mau berubah, sehingga apa yang mereka tuliskan pada tahap write hanya hasil pendapat sendiri tidak hasil kolaborasi dengan teman kelompok.

Hasil pengujian hipotesis ketiga menunjukkan bahwa pemahaman konsep siswa berkemampuan awal rendah yang belajar dengan strategi pembelajaran TTW lebih tinggi dari pemahaman konsep siswa yang belajar dengan pembelajaran konvensional. Hal ini disebabkan siswa berkemampuan awal rendah yang diajarkan dengan strategi pembelajaran TTW sudah terbiasa membahas soal-soal pada tiap pertemuan melalui kegiatan diskusi kelompok dan berinteraksi dengan teman sekelompoknya jika mengalami kesulitan bisa minta penjelasan teman sekelompoknya.

Berdasarkan pengamatan, selama belajar dengan strategi pembelajaran TTW siswa lebih aktif belajar, meskipun ketika pertemuan pertama siswa masih terlihat belum terbiasa dalam 
belajar karena melaksanakan tahap-tahap strategi pembelajaran TTW, namun pada pertemuan berikutnya siswa sudah mulai terbiasa dengan strategi pembelajaran TTW dan terlihat aktif dan antusias dalam belajar.

Pada pembelajaran konvensional, guru menjelaskan materi pelajaran kemudian guru memberikan contoh soal dan diikuti dengan memberikan latihan untuk siswa, dan guru memberikan pekerjaan rumah. Sehingga siswa tidak terlibat langsung dalam membangun pemahaman terhadap materi yang dipelajari. Hasil pengamatan dikelas kontrol siswa masih kesulitan mengerjakan soal yang diberikan dan hanya bisa menjawab soal yang mirip dengan contoh soal guru.

Secara umum, siswa yang menjadi subjek dalam penelitian ini mempunyai pendapat yang positif terhadap matematika dan pembelajarannya. Hal ini dapat dilihat dari minat dan kesungguhan siswa terhadap matematika dan pembelajarannya sehingga siswa mau menerima strategi yang digunakan guru.

Demikian pula, pendapat yang positif dikemukakan siswa terhadap strategi pembelajaran TTW dalam diskusi kelompok karena siswa merasa tidak sulit mendiskusikan matematika, dapat saling membantu sesama teman dan belajar bersama dalam kelompok. Sehingga memunculkan tanggung jawab dan kebersamaan. Memunculkan minat untuk mengemukakan pendapat, dan kemampuan siswa tetap dapat dilihat oleh guru. Meskipun demikian, dalam pelaksanaannya ada hal-hal yang harus dibenahi di antaranya siswa harus dilatih untuk lebih bersikap terbuka terhadap pendapat teman dan mengurangi ketergantungan yang berlebihan kepada guru.

Pendapat siswa terhadap soal-soal kemampuan pemahaman konsep dan komunikasi matematis pun sangat positif karena siswa memandang penyelesaian soal dapat digunakan untuk menyederhanakan situasi masalah, menambah pemahaman materi yang dipelajari, dan memberi manfaat untuk kehidupan sehari-hari.

\section{KESIMPULAN}

Berdasarkan hasil analisis dan pembahasan diperoleh beberapa kesimpulan yang merupakan jawaban atas pertanyaan-pertanyaan yang diajukan dalam penelitian ini. Selain itu, dalam kesimpulan ini diungkapkan pula beberapa hasil yang ditemukan dalam penelitian. 
1. Kemampuan pemahaman konsep matematis siswa yang mendapatkan strategi pembelajaran TTW lebih tinggi dari pada siswa yang mendapatkan strategi pembelajaran konvensional.

2. Kemampuan pemahaman konsep matematis siswa berkemampuan awal tinggi yang mendapatkan strategi pembelajaran TTW tidak lebih tinggi dari pada siswa yang mendapatkan strategi pembelajaran konvensional.

3. Kemampuan pemahaman konsep matematis siswa berkemampuan awal rendah yang mendapatkan strategi pembelajaran TTW lebih tinggi dari pada siswa yang mendapatkan strategi pembelajaran konvensional.

4. Kemampuan komunikasi matematis siswa yang mendapatkan strategi pembelajaran TTW lebih tinggi dari pada siswa yang mendapatkan strategi pembelajaran konvensional.

5. Kemampuan kemampuan komunikasi matematis siswa berkemampuan awal tinggi yang mendapatkan strategi pembelajaran TTW lebih tinggi dari pada siswa yang mendapatkan strategi pembelajaran konvensional.

6. Kemampuan kemampuan komunikasi matematis siswa berkemampuan awal rendah yang mendapatkan strategi pembelajaran TTW tidak lebih tinggi dari pada siswa yang mendapatkan strategi pembelajaran konvensional.

7. Siswa memberi respon yang positif terhadap penerapan strategi pembelajaran TTW. Hal ini terlihat dari pendapat siswa yang menganggap matematika tidak sulit untuk didiskusikan bahkan dapat meningkatkan pemahaman konsep dan komunikasi matematis yang dipelajari.

\section{DAFTAR PUSTAKA}

Arikunto, Suharsimi. 2006. ProsedurPenelitianSuatuPendekatanPraktik. Jakarta: PT RinekaCipta.

Huda, Miftahul. 2011. Cooperative Learning Metode, Teknik, Struktur Dan Model Penerapan. Yogyakarta: Pustaka Pelajar.

Maula, Nikmatul. 2012. “Model pembelajaran Think-Talk-Write (TTW)”.(Online), (http://maulanikmatul.blogspot.com/2012/01/model-pembelajaran-think-talk-writettw.html, diakses tanggal 17 Maret 2013)

Martinis Yamin dan Bansu. I. Antasari. (2008). "Taktik Pengembangan Kemampuan Individual Siswa". Gaung Persada Press: Jakarta.

Mulyono. 2009. Pendidikan Bagi Anak Berkesulitan Belajar. Jakarta : Rineka Cipta. 